\title{
Determination of age and growth of the horned octopus Eledone cirrhosa (Cephalopoda: Octopoda) using stylet increment analysis
}

\author{
Marcos Regueira ${ }^{1,2}$, Ángel F. González ${ }^{1}$, Ángel Guerra ${ }^{1}$ \\ ${ }^{1}$ Instituto de Investigaciones Marinas CSIC, Eduardo Cabello 6, 36208 Vigo, Spain. E-mail: regueira@iim.csic.es \\ ${ }^{2}$ Departamento de Biologia, Universidade de Aveiro. 3810-193 Aveiro, Portugal.
}

\begin{abstract}
Summary: Age and growth of the horned octopus Eledone cirrhosa are estimated for the first time by stylet increment analysis. Specimens were collected between March 2009 and March 2010 from the commercial trawl fishery operating off northwestern Iberian coasts. A pool of stylets representing all size classes were defined by means of modal progression analysis performed separately for each sex in northern and western fishing grounds over a total of 2220 individuals (306 males and 595 females from the northern fishing ground; and 379 males and 940 females from the western fishing ground). In total, 122 stylets belonging to individuals with a total weight ranging from 67 to $950 \mathrm{~g}$ were successfully analysed. Age of the specimens was estimated assuming a daily deposition rate of growth increments within the stylet. Estimated age of the specimens varied from 106 to 516 days. Differential longevity between sexes was observed, with females reaching a life span of 17 months while males attained reached only 14 months, although the possibility that this difference might be even greater is discussed. Based on estimated age, hatching date was back-calculated and it was concluded that hatching occurs throughout the year, with a peak in winter. Relative instantaneous growth rates estimated for 90 -day age classes, ranged from $0.03 \%$ to $2.17 \%$ of body weight per day, depending on age. The results obtained are compared with the information available on this species.
\end{abstract}

Keywords: Eledone cirrhosa; stylet increment analysis; age; life span; growth; NW Iberian Peninsula.

Determinación de la edad y el crecimiento del pulpo blanco Eledone cirrhosa (Cephalopoda: Octopoda) mediante el análisis de incrementos en el estilete

Resumen: La edad y el crecimiento del pulpo blanco Eledone cirrhosa son estimados por primera vez mediante el análisis de incrementos del estilete (SIA). Los especímenes fueron obtenidos, entre marzo de 2009 y marzo de 2010, provenientes de la pesquería de arrastre comercial que opera en la costa noroeste de la Península Ibérica. Un conjunto de estiletes, en representación de todas las clases de tamaño, fue definido mediante un análisis de progresión modal realizado por separado para cada sexo en los caladeros del norte y oeste, sobre un total de 2220 individuos (306 machos y 595 hembras procedentes de la costa norte y 379 machos y 940 hembras de la costa oeste). Un total de 122 estiletes, pertenecientes a especímenes con un peso total de entre 67 y 950 g, fueron analizados con éxito. La edad de los especímenes se calculó asumiendo una tasa de deposición diaria de los incrementos de crecimiento en el estilete. La edad estimada de los especímenes fue de entre 106 y 516 días. Se observó una longevidad diferencial entre sexos; en las hembras se registró una esperanza de vida de hasta 17 meses, mientras que los machos tan sólo alcanzaron 14 meses, aunque se discute la posibilidad de que esta diferencia podría ser aún mayor. En base en la edad estimada se calculó la fecha de eclosión, concluyendo que la eclosión se produce durante todo el año, con un repunte durante el invierno. Las tasas de crecimiento relativo instantáneo $(\mathrm{G})$, estimadas para clases de edad de 90 días, variaron desde el $0.03 \%$ hasta el $2.17 \%$ del peso total por día, dependiendo de la edad. Los resultados obtenidos se comparan con la información disponible sobre esta especie.

Palabras clave: Eledone cirrhosa; análisis de incrementos del estilete; edad; longevidad; crecimiento; noroeste de la península Ibérica.

Citation/Como citar este artículo: Regueira M., González A.F., Guerra A. 2015. Determination of age and growth of the horned octopus Eledone cirrhosa (Cephalopoda: Octopoda) using stylet increment analysis. Sci. Mar. 79(1): 71-78. doi: http://dx.doi.org/10.3989/scimar.04137.23A

Editor: P. Sánchez.

Received: August 12, 2014. Accepted: February 11, 2015. Published: February 26, 2015.

Copyright: (c) 2015 CSIC. This is an open-access article distributed under the Creative Commons Attribution-Non Commercial Lisence (by-nc) Spain 3.0. 


\section{INTRODUCTION}

Age determination is fundamental for understanding and properly estimating various parameters that determine the biology of cephalopod species, such as growth rate, population structure, longevity, mortality, productivity and the recruitment process (Boyle and Rodhouse 2005). Furthermore, our knowledge of these processes, as well as conditioning factors, is essential to the proper management of fisheries resources. Due to the high intrinsic growth variability and consequent mixing of individuals of different ages (micro-cohorts) within the same size range, cephalopod studies on age and growth based on length and body weight measures are not considered as accurate as those undertaken using hard structures (Jackson 1994). However, the methodologies based on the external morphology of specimens are still employed because they are low-cost and easy to apply in most fisheries (Semmens et al. 2004).

Direct ageing methods, based on reading growth increments in hard structures, have been developed to determine age in cephalopods. Particularly in octopods, beaks have provided some positive results in reading growth increments of Octopus vulgaris paralarvae (HernandezLopez et al. 2001) and adults (Canali et al. 2011, PeralesRaya et al. 2010). Stylet Increment Analysis has been applied and daily growth increment deposition has been validated in Octopus vulgaris (Hermosilla et al. 2010), Octopus pallidus (Doubleday et al. 2006), Octopus maya (Rodríguez-Domínguez et al. 2013) and Octopus (cf) tetricus (Leporati and Hart 2014).

The horned octopus, Eledone cirrhosa (Lamarck, 1798), is a medium-size benthic octopod that is widely distributed over the continental shelves of the northeastern Atlantic and Mediterranean Sea (Boyle 1983). This species breeds throughout the year, although in the northwest Iberian Peninsula reproduction mostly occurs between late spring and early summer (Regueira et al. 2013). The reproductive peak in the western Mediterranean, at a similar latitude to the above-mentioned study, is similarly timed (Lefkaditou and Papaconstantinou 1995, Mangold-Wirz 1963, Moriyasu 1988). However, studies performed in Scotland indicate that egg-laying occurs later, between July and September (Boyle and Knobloch 1983), suggesting that latitude, through day-night duration, is an important parameter influencing sexual maturation (Regueira et al. 2013).

Hatching season for this species in northern Europe has been assumed to happen mainly between October and December, about three or four months later than the sexual maturation peak (Boyle 1983). Little is known about early life stages of this species. Given the size of the eggs (about $7 \mathrm{~mm}$ ), considered intermediate compared with those of other octopuses, hatchlings are certainly planktonic, but probably only for a matter of days, during which they remain near the bottom (Boyle 1983). In view of all the above, a 20-month lifecycle has been postulated for this species in north European waters (Boyle and Knobloch 1982), although this is unverified due to the lack of studies focusing on age and population structure of the species.

E. cirrhosa landings in Galician commercial harbours show a marked seasonality, typically associated with

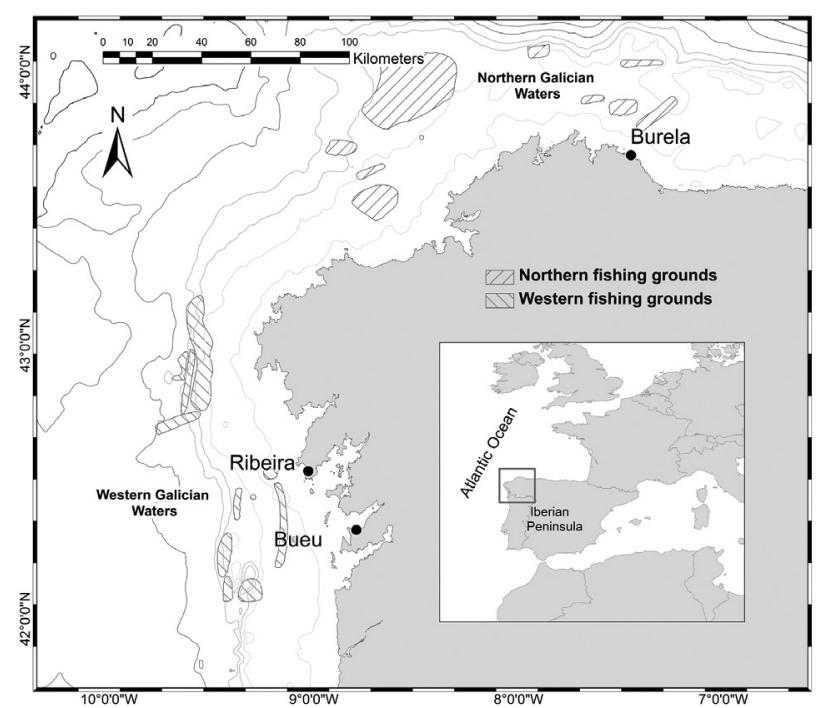

Fig. 1. - Location of the fishing ports where the Eledone cirrhosa specimens were between March 2009 and March 2010. Trawling fishing grounds catalogued in each zone are indicated.

cephalopods, which have a short life span and rapid population turnover (Sánchez and Martín 1993). Amount of captures also showed an increasing trend over the last ten years (Regueira et al. 2014). However, the biology of this octopus is still poorly studied in this region.

The main objective of the present study was to estimate age and growth of the horned octopus Eledone cirrhosa during its juvenile and adult stages using growth increments in stylets and to obtain new insights into aspects of the lifecycle of this species, such as life span and hatching season, in northwestern Iberian Peninsula waters.

\section{MATERIALS AND METHODS}

From March 2009 to March 2010 samples of commercially caught horned octopus (E. cirrhosa) were collected monthly in three Galician (northwestern Iberian Peninsula) fishing harbours: Burela (north) and Ribeira or Bueu (west). This species is caught as a by-catch in the multi-species trawl fishery operating in this whole area. Vessels landing their captures in $\mathrm{Bu}-$ rela operate on northern fishing grounds, while those landing in Bueu and Ribeira operate on western fishing grounds (Fig. 1).

In total, 2220 individuals of E. cirrhosa (306 males and 595 females from the northern fishing ground; and 379 males and 940 females from the western fishing ground) were processed. Measurements of each specimen included body weight (BW), eviscerated body weight (EBW) and dorsal mantle length (DML). Lengths and weights were measured to the nearest $0.1 \mathrm{~cm}$ and the nearest $0.1 \mathrm{~g}$, respectively. Since specimens were mostly intact, no bias in weight measures was expected. The macroscopic maturity scale of Inejih (2000) was adapted to assign a specific maturity stage to each individual. For males this scale was as follows: I, immature; II, maturing; III, pre-spawning, with some spermatophores in Needham's sac; and IV, mature, fully developed spermatophore. For females the scale was as follows: I, immature; II, maturing; III, pre-spawning; IV, mature; and 


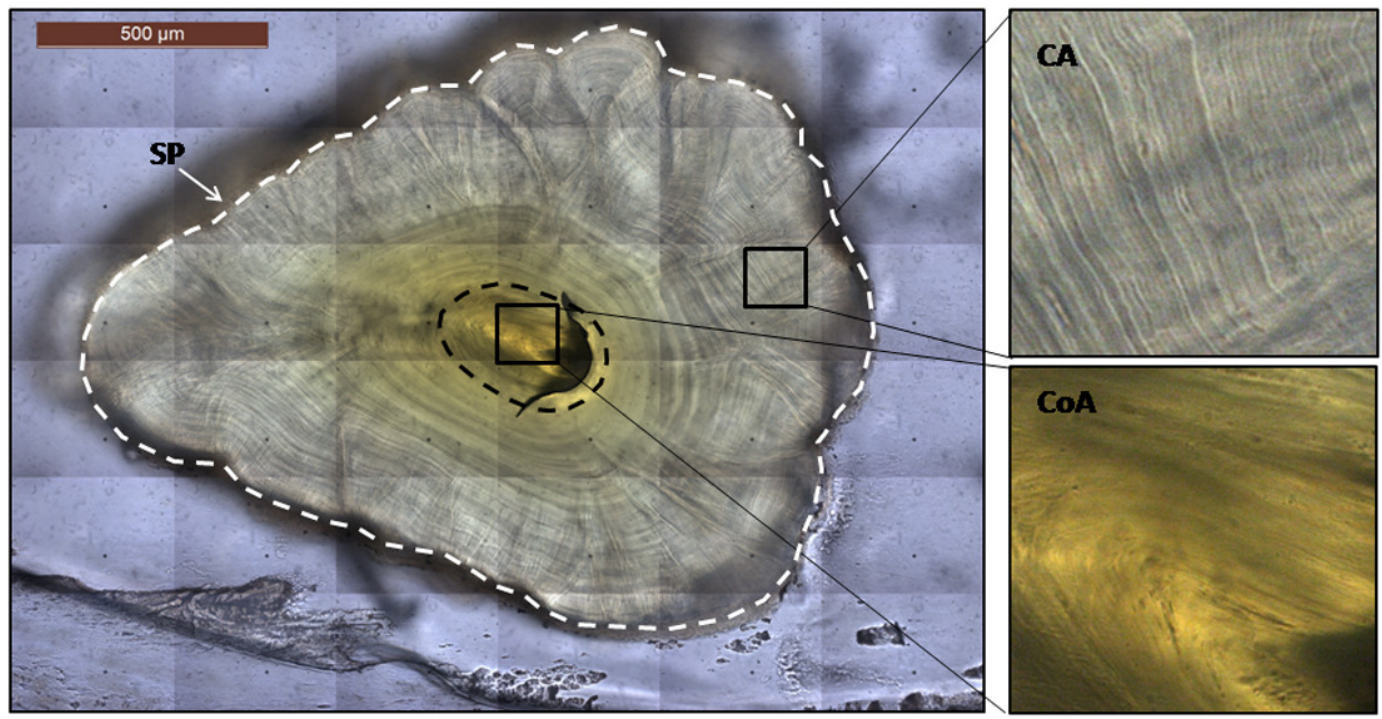

Fig. 2. - Composite image of an Eledone cirrhosa stylet preparation, showing the counted area (CA, the area between dashed lines), in which growth rings are discernible, and the core area ( $\mathrm{CoA}$, the area within the dashed black line), where the growth rings appear obliterated. The number of growth rings in CoA was extrapolated following the deposition rate found in CA. Stylet perimeter (SP) is indicated by the white dashed line.

$\mathrm{V}$, post-spawning. Stylets of 30 specimens of each sex and fishing ground were taken monthly and stored in 70 $\%$ ethanol until preparation.

In order to identify size classes (grouped in $5 \mathrm{~mm}$ DMLs) and structure sampling, a modal progression analysis (MPA) was performed separately for males and females from both northern and western fishing grounds using the Bhattacharya (1967) method and FISAT software. Subsequently, three individuals representing each size class, sex and fishing ground were taken for stylet increment analysis.

Permanent stylet preparations were made following four steps according to the Barratt and Allcock (2010) methodology. First, transversal sections of stylet approximately 1-2 mm thick were obtained using a razor blade. Second, sections were dehydrated by successive immersions for one hour in $70 \%, 90 \%$ and absolute ethanol. Third, sections were embedded in low-viscosity acrylic resin (LR White ${ }^{\mathrm{TM}}$, London Resin Company). Fourth, in order to achieve a better light transmission and therefore a clearer view of the growth rings, the samples were ground and polished on both sides.

Samples were observed under a transmitted light microscope connected to an image analysis device equipped with LAS v1.4 software. Stylet sections were photographed at $400 \times$ magnification under full light power, with the condenser adjusted to optimize brightness and contrast. A series of pictures were taken of each stylet section, covering its entire surface. Each complete image comprised 4 to 54 partial pictures.

The stylet sections consisted of a striped-concentric surface surrounding a core, where each growth increment appears as a double band, comprising an optically translucent ring and a dark one (Fig. 2). Each pair of bands was considered as one growth increment and, therefore, as a daily time indicator in the life of E. cirrhosa.

In total, 264 stylets were prepared and photographed, and 123 were considered unreadable due to focusing or sample quality deficiencies. Two non-consecutive counts of growth increments were carried out in the remaining 141 stylets, from the outer to inner zone. When the difference between counts exceeded 10\% (Doubleday et al. 2006, Hermosilla et al. 2010), an extra count was undertaken. After eliminating samples with differences greater than 10\%, 122 samples were accepted. These stylets represented 27 females and 39 males from the western fishing ground, and 33 females and 23 males from the northern fishing ground.

A preliminary observation of the photos taken from these stylet sections showed that the core area of the stylet was useless for reading, as found in other similar studies (e.g. Doubleday et al. 2006). Thus, Core Area $\left(\mathrm{CoA}, \mathrm{mm}^{2}\right)$ and Counted Area $\left(\mathrm{CA}, \mathrm{mm}^{2}\right)$ of each stylet were measured from pictures. The number of increments in the CoA was estimated by extrapolation following the increment deposition rate found in CA. This deposition rate for each stylet was obtained by fitting the potential relationship between $\mathrm{CA}$ and the number of counted increments. After logarithmic transformation, a t-test was preformed to compare both the slope and the intercept in growth increment deposition rate between males and females (Zar 1984).

Based on previous studies on age validation by stylet increment analysis performed in three octopus species (Doubleday et al. 2006, Hermosilla et al. 2010, Leporati and Hart 2014) a daily deposition rate of growth increments in the stylet of E. cirrhosa was assumed. Thus, age of the specimens was calculated by adding the estimated growth rings in the CoA and those already counted in the $\mathrm{CA}$, and hatching dates were back-calculated from capture date. Estimated age was then compared between sexes and fishing ground and was also related to BW, EBW and DML of the specimens.

Instantaneous relative growth rate $\left(\mathrm{G}, \% \mathrm{BW} \mathrm{d}^{-1}\right)$ was calculated for each 90-day age class in order to obtain growth trends during different ontogenic periods, using the equations given by Forsythe and Van Heukelem (1987): 


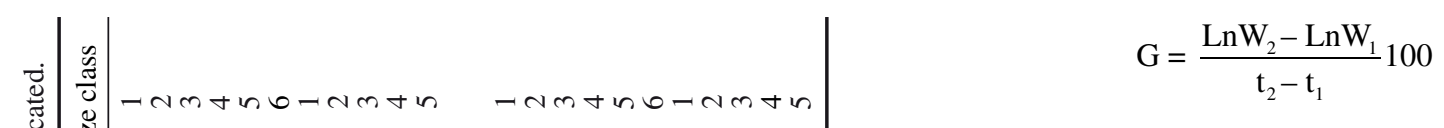

where $\mathrm{W}_{2}$ is the $\mathrm{BW}$ at age $t_{2}$ and $\mathrm{W}_{1}$ is $\mathrm{BW}$ at age $t_{1}$. To estimate $\mathrm{G}$, maximum and minimum $\mathrm{BW}$ for each 90-day age class were used.

Given that assumptions of normality and homoscedasticity were not fulfilled, Spearman-rank correlation $\left(r_{s}\right)$ was used to evaluate covariation between numerical variables. Differences between categorical predictors were tested using non-parametric Kruskal-Wallis test for multiple comparisons and Mann-Whitney for paired comparisons, adjusting alpha by the Bonferroni approach $\left(\alpha_{t}\right)$ with the purpose of controlling Type I error across tests (Zar 1984). All data were treated with the STATISTICA 6.0 statistical software.

\section{RESULTS}

\section{Modal progression analysis}

MPA was performed separately for females and males of western and northern fishing grounds off Galician coasts. DML of the 2220 considered specimens ranged from 57 to $158 \mathrm{~mm}$ for males and from 45 to $180 \mathrm{~mm}$ for females. BW ranged between 40 and $634 \mathrm{~g}$ for the males and from 15 to $1090 \mathrm{~g}$ for females. Table 1 shows the monthly size classes per sex and fishing ground determined by stylet increment analysis. During the period between March 2009 and March 2010, six size classes for females on both fishing grounds were identified. Conversely, males showed only five size classes in this period. A maximum of three simultaneous size classes per group in one month were detected (Table 1). Size classes were followed over time for as much as nine months.

\section{Stylet increment analysis}

The 122 stylets finally accepted for counting growth increments comprised 60 females (BW: 67 to $950 \mathrm{~g}$, DML: 73 to $174 \mathrm{~mm}$ ) and 62 males (BW: 68 to $498 \mathrm{~g}$, DML: 64 to $140 \mathrm{~mm}$ ).

Stylet sections varied widely in shape, from nearly circular to much more irregular. No clear zonation, apart from the readable and unreadable areas, was observed. The readable area constituted between $90 \%$ and $99.7 \%$ of the total stylet section area. In other words, assuming a circular-shaped stylet section, the unreadable zone was equivalent to the internal area defined by a radius of between $5.5 \%$ and $31.62 \%$ of the total radius.

No significant $(p>0.05)$ differences were found between the slopes and the intercept in growth increment deposition rates between females and males, indicating that sex has no effect on deposition rates. Therefore, a general equation was estimated from combined data of both sexes. The equation relating the readable area of the stylet and the counted increments (CI) in this area was:

$$
\mathrm{CI}=241.7 * \mathrm{CA}^{0.507} ; \mathrm{R}^{2}=0.756 \text { (Fig. 3). }
$$

Based on this equation, growth rings in the CoA were estimated. 


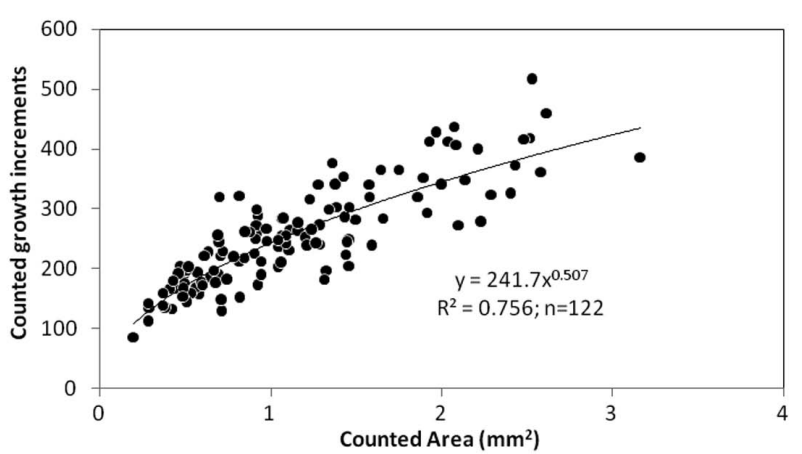

Fig. 3. - Relationship between counted area (CA) and number of counted growth increments in the stylet section of Eledone cirrhosa.
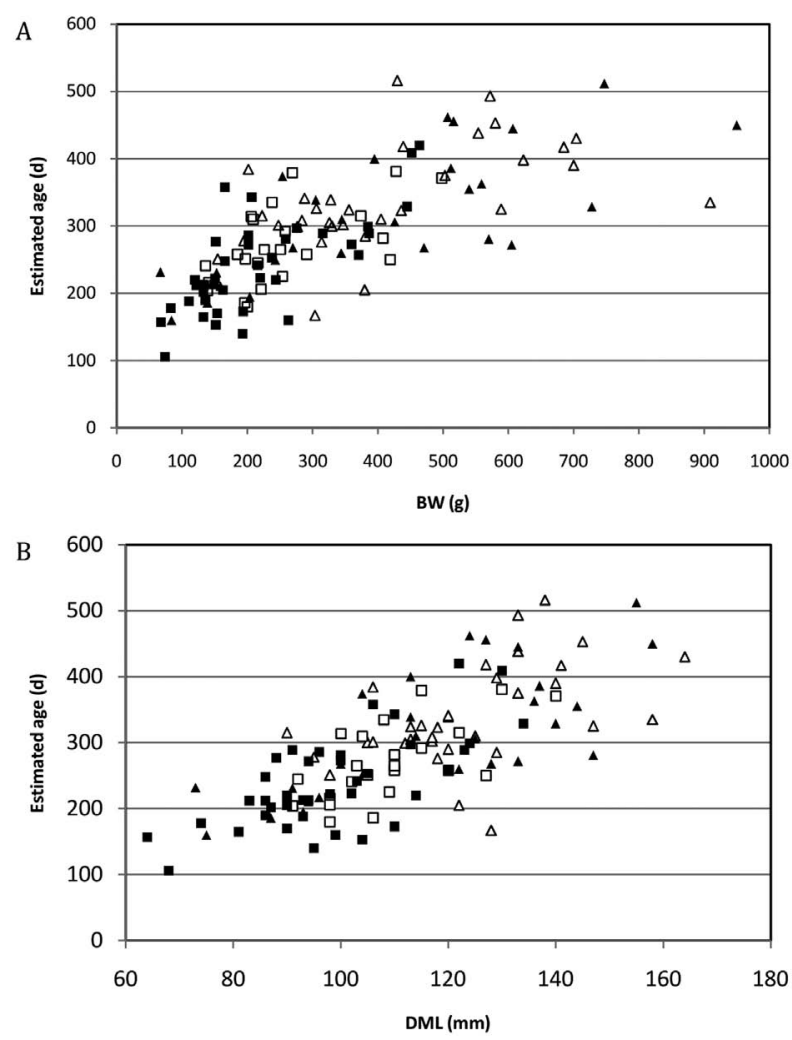

Fig. 4. - Scatterplots showing estimated age (d) of each Eledone cirrhosa specimen versus BW in grams (A) and DML in millimetres (B). Full squares, west coast males $(n=39)$; open squares, north coast males $(n=23)$, full triangles, west coast females $(n=27)$; and open triangles, north coast females $(n=33)$.

\section{Estimated age}

Significant differences $\left(p<\alpha_{t}\right)$ in the estimated age between males and females were found in both fishing grounds; however, age remained constant for each sex regardless of the origin $\left(\mathrm{p}>\alpha_{\mathrm{t}}\right)$. Overall estimated age varied from 160 to 516 days for females, and from 106 to 420 days for males. Estimated age in the northern fishing ground ranged from 167 to $516 \mathrm{~d}$ (mean \pm SD: $339.9 \pm 76$ d) for females and from 180 to 381 (mean \pm SD: $270.8 \pm 58$ d) for males. In the western fishing ground, estimated age ranged from 160 to 512 days (mean \pm SD: $315.4 \pm 96 \mathrm{~d}$ ) for females, and from 106 to 420 days (mean \pm SD: $239.6 \pm 71$ d) for males.

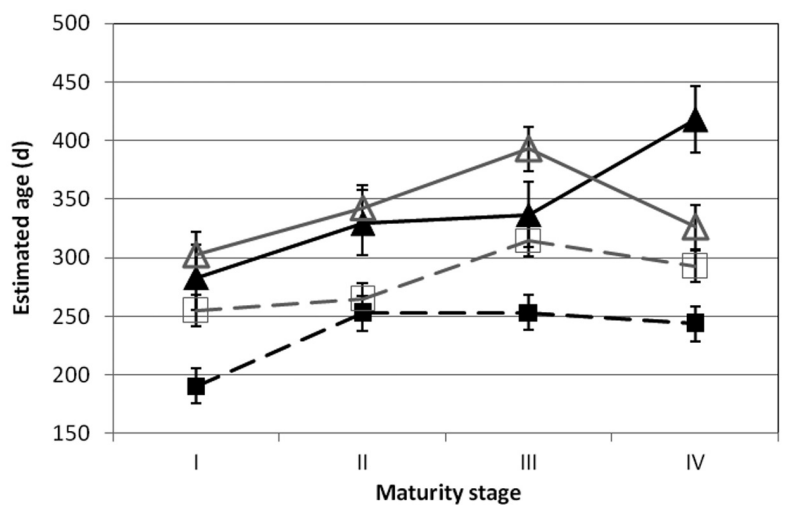

Fig. 5. - Mean age per maturation stage by sex and fishing ground. Full squares, west coast males $(n=39$; black dotted trend line); open squares, north coast males $(\mathrm{n}=23$; grey dotted trend line); full triangles, west coast females ( $\mathrm{n}=27$; continuous black line); and open triangles, north coast females ( $n=33$; continuous grey line). No postspawning females were found.

The estimated age of the specimens was significantly correlated with all measurements considered (BW, EBW and DML) for pooled data and also when analysing sexes and fishing grounds separately $(\mathrm{p}<0.05)$. The best predictor of age for females was BW, with a $r_{s}$ of 0.77 and 0.62 for the western and northern fishing ground, respectively. However, the best predictor proved to be DML $\left(r_{s}=0.64\right)$ for males on the north coast, and EBW $\left(r_{s}=0.72\right)$ for males on the west coast. Figure 4 illustrates the relationships between estimated age and BW and DML.

Age of mature males ranged from 186 to 381 days (mean \pm SD: $292.8 \pm 74$ ) on the northern fishing grounds, while it varied between 170 and 286 days (mean \pm SD: $243.7 \pm 40$ ) in western waters. With the exception of one specimen with an estimated age of 167 days, the estimated age of mature females ranged between 310 and 453 days (mean \pm SD: $348.8 \pm 55$ ) in the northern fishing grounds and from 386 to 450 days (mean \pm SD: $418 \pm 45$ ) on the western fishing grounds (Fig. 5). No post-spawning females were found.

\section{Hatching date vs. size class}

Hatching dates of individuals captured between March 2009 and March 2010 ranged from December 2007 to October 2009 and hatching occurred throughout the year, with a peak in winter (Fig. 6).

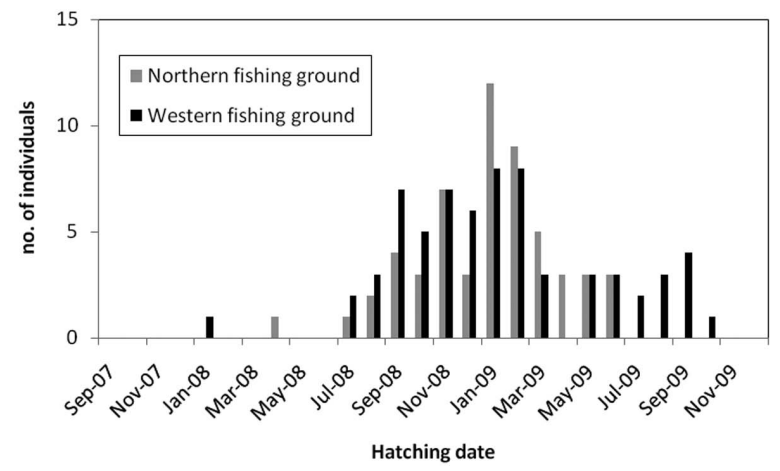

Fig. 6. - Hatching date histogram, resulting from back-calculation according to capture data and estimated age of the 122 successfully aged Eledone cirrhosa specimens. 


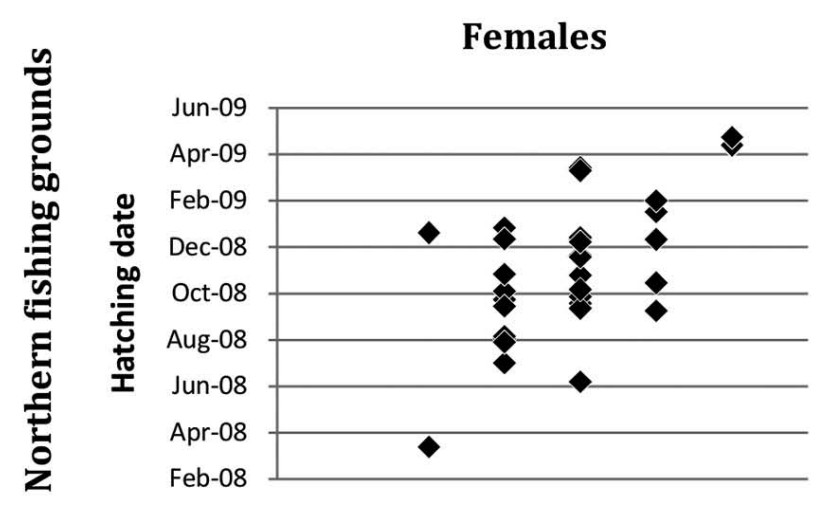

Males
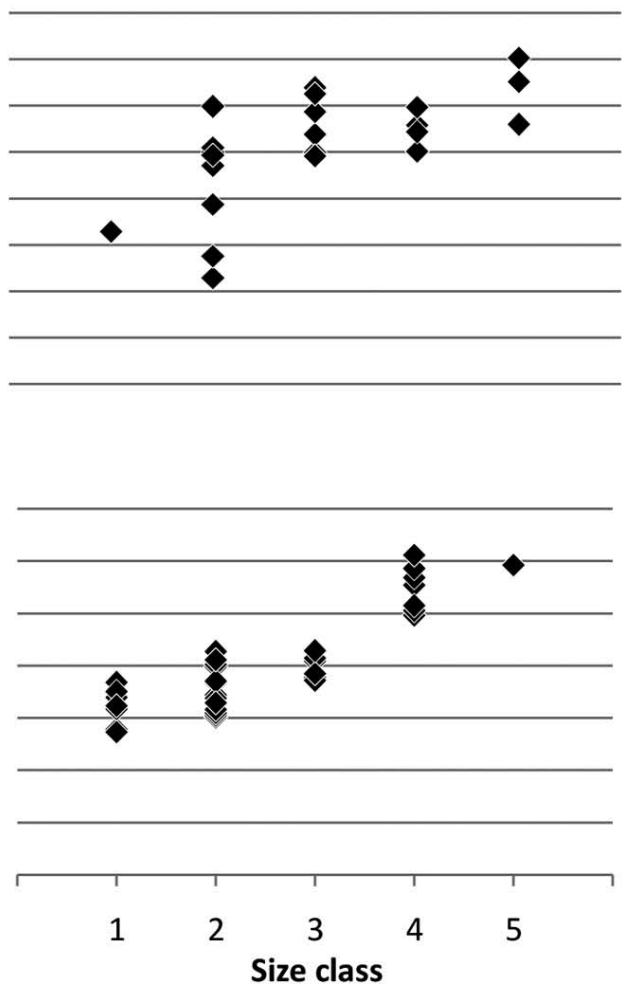

Fig. 7. - The figure illustrates the application of MPA as a proxy for defining age classes in Eledone cirrhosa. Specimens of each sex and fishing ground are displayed separately according to their estimated hatching date and the size class they belong to. Size classes were previously defined by MPA and followed in time, so specimens of a particular size class would be expected to have hatched at about the same date.

Nevertheless, the range of hatching dates of the specimens belonging to consecutive size classes largely overlap in many cases.

Size classes determined by MPA partially match predicted hatching date (Fig. 7), but they do not predict age groups, since hatching dates of individuals belonging to different size classes overlap. Thus, paired comparisons of hatching date between consecutive size classes showed no significant differences $\left(\mathrm{p}>\alpha_{t}\right)$. Differences in estimated age between individuals assigned to a particular size class at the same month ranged from 6 to 286 days, with a mean of $78.1 \pm 64$ days (Mean \pm SD). Regarding areas and sex, the difference between western females was $84.4 \pm 76$ days, while that between northern females was $92.8 \pm 84$ days. This latter group achieved the largest differences in estimated age within a particular cohort: up to 286 days. For males, the difference was $66.9 \pm 37$ days, and $60.6 \pm 38$ days for the western and northern coasts, respectively.

\section{Growth}

Relative instantaneous growth rates $(\mathrm{G})$ generally decreased with age (Fig. 8). Values of $\mathrm{G}$ varied between age classes from $0.03 \%$ to $2.17 \%$ of BW per day (Mean \pm SD: $1.07 \pm 0.54)$. Male $\mathrm{G}$ varied from $0.03 \%$ to $1.5 \%$ (Mean \pm SD: $0.97 \pm 0.51$ ); female $G$ varied from $0.33 \%$ to $2.17 \%$ (Mean \pm SD: $1.15 \pm 0.58)$.

Although the Student t-test does not reject the null hypothesis of homogeneity of slopes $(\mathrm{p}>0.05)$, young individuals from the western fishing ground have higher growth rates than those from the north according to the

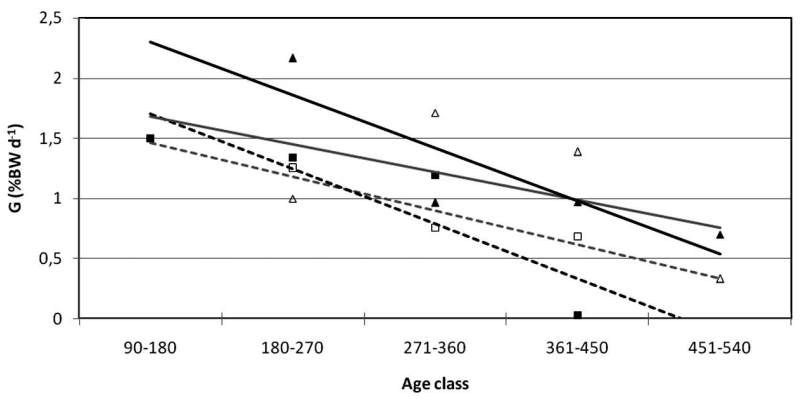

Fig. 8. - Eledone cirrhosa instantaneous relative growth rate (G) in $\mathrm{BW}\left(\% \mathrm{BW} \mathrm{d}^{-1}\right)$ and trending lines per 90 -day age class. Full squares, west coast males (black dotted trend line); open squares, north coast males (grey dotted trend line); full triangles, west coast females (continuous black line); and open triangles, north coast females (continuous grey line).

calculated G. However, their growth rate subsequently decreases more sharply, reaching lower values of $\mathrm{G}$.

The adjusted slope is similar in both sexes within each sampled area but the value of the intercept differs between sexes, and males attained a lower $\mathrm{G}$ than correspondingage females.

\section{DISCUSSION}

Our results show that E. cirrhosa hatches throughout the year in northwestern Iberian waters, with a peak in January. The comparison of our data with the reproductive cycle in this area, where the maximum gonadosomat- 
ic index of females peaks in June (Regueira et al. 2013), indicates that the period between maturity peak and egg hatching is about six months. Considering that embryonic development at $16^{\circ} \mathrm{C}$ takes about 110 days in this species (Mangold et al. 1971) and since sea bottom temperature on the northwestern Iberian continental shelf ranges between $11^{\circ} \mathrm{C}$ and $14^{\circ} \mathrm{C}$ (Gago et al. 2011), this longer time period should be expected. Experiments in culture indicate that females of E. cirrhosa may copulate several weeks before egg laying begins and can preserve sperm for up to six weeks (Mangold et al. 1971). Therefore, although the reproductive peak occurs in June, egg laying may be delayed until the summer and hatching until December.

A significant differential longevity between sexes was observed in E. cirrhosa, with females living longer than males. This cannot be established as a general tendency in octopods on the basis of previous studies. Neither Hernandez-Lopez et al. (2001) nor Canali et al. (2011) found significant differences in lifespan between sexes in $O$. vulgaris. Conversely, Leporati et al. (2008) found significant differences in age by reading $O$. pallidus stylets, although males were significantly longer-lived than females. This lack of uniformity in the published results could suggest inconsistencies in the sampling method rather than physiological differences between species. These inconsistencies may be due to a different catchability between sexes during different life stages, as might result from females of E. cirrhosa migrating to shallow water to spawn (Regueira et al. 2014); during this reproductive migration, they may be more vulnerable to fishing, while a proportion of males remain in deeper areas, outside the fishing grounds worked by trawlers. This could be the reason why females seem to be much more abundant than males in this fishery. On the other hand, females of E. cirrhosa lay their eggs on rocky substrate in a similar way to $O$. vulgaris, and certainly not on open smooth muddy or sandy bottoms, and probably brood the eggs (Mangold et al. 1971). If this is so, females might not be captured during this period, while males could be captured throughout their life. The absence of postspawning females in this study supports this fact. Given the above, lifespan difference between sexes should be up to almost eight months. Combining this with the results on age estimate obtained in this study (maximum age of 517 days), the life span of female E. cirrhosa should be around two years, agreeing with the hypothesis of Boyle (1986) for Scottish populations.

According to minimum estimated ages, recruitment to the fishery of E. cirrhosa in northwestern Iberian waters should occur when animals reach 3-4 months old. This also agrees with the fishery catch pattern of the species in northwestern Galician waters, in which a peak of captures corresponding to new recruits takes place around May (Regueira et al. 2014). Thus, the concluded chronological pattern matches that proposed by Mangold et al. (1971) when analysing embryonic development of the species.

Despite the significant correlation found between size and age, in view of our results, MPA seems not to provide a suitable vision of age structure in E. cirrhosa populations. The application of MPA as a tool for inferring age structure of cephalopod populations has been rejected before, mainly due to the high intrinsic variability in growth rates (Forsythe and Van Heukelem 1987) and also because neither length nor weight are good indicators of the size of a soft-bodied animal (Forsythe 1984). Although some authors have suggested its validity if it can correct the observation bias introduced by the size-selective fishing gear (Keyl et al. 2011), our results support the former hypothesis, given the high size diversity between same-age specimens. This individual diversity is also illustrated by the wide variety of mathematical models used to define the growth of cephalopods, due to the unsuitability of a single model account for the wide variability in size of individuals belonging to a single age class (Semmens et al. 2004). Given this lack of consensus, it seems likely that cephalopods have different types of growth in different stages of development, so the growth rates set out in this work are only valid for the benthic life stage and cannot be extrapolated to embryonic and planktonic stages.

Based on size at first maturity (DML50\%) estimated for this species on northwestern Iberian coasts (Regueira et al. 2013) and DML-Age relationships in this paper, females should achieve maturity at around one year old, while males should do so at approximately 8 or 9 months.

Estimated growth rates are similar results to those estimated for other octopods in the wild, such as Octopus mimus (0.09-1.25\%) (Cortez et al. 1999). According to experiments in the laboratory, octopuses generally demonstrate two growth phases: an initial rapid exponential phase and a slower power growth phase (Semmens et al. 2004). Therefore, a progressive moderation of growth rate would be expected, or at least in young individuals it should remain stable. Given the limited amount of successfully aged individuals, although the observed trends are plausible, further analysis will be needed to accurately determine such changes in growth rates as well as for embrionary and planktonic phases. Moreover, as in other cephalopods, different micro-cohorts may have different growth rates depending on the time of hatching (Pierce and Guerra 1994). The lack of precise catch location data could explain part of the variability in our results, as well as reported segregated distribution by sex and size (Regueira et al. 2014), since individuals caught in different areas may be subjected to diverse abiotic and biotic conditions affecting growth processes (Pierce et al. 2008).

The method for sample preparation described by Barrat and Allcock (2010) and applied herein provided durable samples, which were kept throughout the process of experimentation and photography. This proves the suitability of the method for age studies in Eledone cirrhosa.

In the future, the results of the present study will need further validation, not only because the deposition rate of growth rings could have a different periodicity to a day, but also because stylet formation and growth processes remain unknown during embryonic development and early life stages and, as observed in other structures such as statoliths (González et al. 2010), the central area of the stylet may undergo compaction during early growth. That would make it harder to estimate the number of rings in this area and could bias the results on estimated age. However, the concordance between this interpretation of the population structure by mean of age estimates, the reproductive cycle described for the species and the pattern of catches supports the validity of what is concluded in this paper. 


\section{ACKNOWLEDGEMENTS}

This research was supported by the project "Impacto do ambiente sobre o polbo Eledone cirrhosa no sistema de afloramento costeiro das augas de Galicia" (INCITE08PXIB402074PR), funded by the Xunta de Galicia. Marcos Regueira was supported by an FCT grant. We thank M.E. Garci and M.T. Fernández for their help in the dissection of specimens and collection of stylets.

\section{REFERENCES}

Barratt I.M., Allcock, A.L. 2010. Ageing octopods from stylets: development of a technique for permanent preparations. ICES J. Mar. Sci. 67: 1452-1457.

Bhattacharya C.G. 1967. A simple method of resolution of a distribution into Gaussian components. Biometrics. 23: 115-135. http://dx.doi.org/10.2307/2528285

Boyle P.R. 1983. Eledone cirrhosa. In: Boyle P.R. (ed.), Cephalopod life cycles. Vol 1: Species Accounts. Academic Press. London, pp. 365-386.

Boyle P.R. 1986. A descriptive ecology of Eledone cirrhosa (Mollusca: Cephalopoda) in Scottish waters. J. Mar. Biol. Ass. U.K. 66: $855-865$. http://dx.doi.org/10.1017/S0025315400048487

Boyle P.R., Knobloch D. 1982. On growth of the Octopus Eledone cirrhosa. J. Mar. Biol. Ass. U.K. 62: 277-296. http://dx.doi.org/10.1017/S0025315400057283

Boyle P.R., Knobloch D. 1983. The female reproductive cycle of the octopus, Eledone cirrhosa. J. Mar. Biol. Ass. U.K. 63: 71-83. http://dx.doi.org/10.1017/S002531540004981X

Boyle P.R., Rodhouse P.G. 2005. Cephalopods. Ecology and Fisheries, Blackwell Science Ltd, Oxford, 464 pp.

Canali E., Ponte G., Belcari P., et al. 2011. Evaluating age in Octopus vulgaris: estimation, validation and seasonal differences. Mar. Ecol. Prog. Ser. 441: 141-149. http://dx.doi.org/10.3354/meps09399

Cortez T., González Á.F., Guerra Á. 1999. Growth of Octopus mimus (Cephalopoda, Octopodidae) in wild populations. Fish. Res. 42: 31-39.

http://dx.doi.org/10.1016/S0165-7836(99)00040-5

Doubleday Z., Semmens J., Pecl G., et al. 2006. Assessing the validity of stylets as ageing tools on Octopus pallidus. J. Exp. Mar. Biol. Ecol. 338(1): 35-42. http://dx.doi.org/10.1016/j.jembe.2006.06.027

Forsythe J.W. 1984. Octopus joubini (Mollusca: Cephalopoda): a detailed study of growth through the full life cycle in a closed seawater system. J. Zool. 202: 393-417. http://dx.doi.org/10.1111/j.1469-7998.1984.tb05091.x

Forsythe J.W. Van Heukelem W.F. 1987. Growth. In: Boyle P.R. (ed.), Cephalopod Life Cycles Vol 2: Comparative Reviews. Academic Press. London, pp. 135-156.

Gago J., Cabanas J.M., Casas G., et al. 2011. Thermohaline measurements in the continental shelf zone of the NW Iberian Peninsula, 1994-2006. Clim. Res. 48: 219-229. http://dx.doi.org/10.3354/cr00943

González Á.F. Otero J., Pierce G.J. et al. 2010. Age, growth, and mortality of Loligo vulgaris wild paralarvae: implications for understanding of the life cycle and longevity. ICES J. Mar. Sci. 67: 1119-1127. http://dx.doi.org/10.1093/icesjms/fsq014

Hermosilla C.A., Rocha F., Fiorito G., et al. 2010. Age validation in common octopus Octopus vulgaris using stylet increment analysis. ICES J. Mar. Sci. 67: 1458-1463.

Hernandez-Lopez J.L., Castro-Hernandez J.J., Hernandez-Garcia V. 2001. Age determined from the daily deposition of concentric rings on common octopus (Octopus vulgaris) beaks. Fish.
Bull. 99: 679-684.

Inejih C.A. 2000. Dynamique spatio-temporelle et biologie du poulpe (Octopus vulgaris) dans les eaux mauritaniennes: modélisation de l'abondance et aménagement des pêcheries. Ph. D. thesis. Université de Bretagne Occidentale, $251 \mathrm{pp}$.

Jackson G.D. 1994. Application and future potential of statolith increment analysis in squids and sepioids. Can. J. Fish. Aquat. Sci. 51: 2612-2625. http://dx.doi.org/10.1139/f94-261

Keyl F., Argüelles J., Tafur R. 2011. Interannual variability in size structure, age, and growth of jumbo squid (Dosidicus gigas) assessed by modal progression analysis. ICES J. Mar. Sci. 68: 507-518.

http://dx.doi.org/10.1093/icesjms/fsq167

Lefkaditou E., Papaconstantinou C. 1995. Distribution, growth and maturity of Eledone cirrhosa (Cephalopoda: Octopoda) in the Thracian Sea (eastern Mediterranean). Rapp. Comm. int. Mer Médit. 34: 247.

Leporati S.C., Semmens J.M., Pecl G.T. 2008. Determining the age and growth of wild octopus using stylet increment analysis. Mar. Ecol. Prog. Ser. 367: 213-222. http://dx.doi.org/10.3354/meps07558

Leporati S.C., Hart A.M. 2014. Stylet weight as a proxy for age in a merobenthic octopus population. Fish. Res. 161: 235-243. http://dx.doi.org/10.1016/j.fishres. 2014.08.001

Mangold-Wirz K. 1963. Biologie des Céphalopodes bentiques et nectoniques de la Mer Catalane. Vie Milieu 13(Suppl.): 1-285.

Mangold K., Boletzky S.V., Frösch D. 1971. Reproductive biology and embryonic development of Eledone cirrhosa (Cephalopoda: Octopoda). Mar. Biol. 8: 109-117. http://dx.doi.org/10.1007/BF00350926

Moriyasu M. 1988. Analyse de la maturation sexuelle d'Eledone cirrhosa (Cephalopoda: Octopoda) du golfe du Lion. Aquat. Living. Resour. 1: 59-65. http://dx.doi.org/10.1051/alr:1988007

Perales-Raya C., Bartolomé A. García-Santamaría M.T., et al. 2010. Age estimation obtained from analysis of octopus (Octopus vulgaris Cuvier, 1797) beaks: Improvements and comparisons. Fish. Res. 106: 171-176. http://dx.doi.org/10.1016/j.fishres.2010.05.003

Pierce G.J., Guerra A. 1994. Stock assessment methods used for cephalopod fisheries. Fish. Res. 21: 255-285. http://dx doi.org/10.1016/0165-7836(94)90108-2

Pierce G.J., Valavanis V.D., Guerra A., et al. 2008. A review of cephalopod-environment interactions in European Seas. Hydrobiologia. 612: 49-70. http://dx.doi.org/10.1007/s10750-008-9489-7

Regueira M., González A.F., Guerra Á., et al. 2013. Reproductive traits of horned octopus Eledone cirrhosa in Atlantic Iberian waters. J. Mar. Biol. Ass. U.K. 93: 1641-1652. http://dx.doi.org/10.1017/S0025315413000118

Regueira M., González A.F., Guerra A. 2014. Habitat selection and population spreading of the horned octopus Eledone cirrhosa (Lamarck, 1798) in Galician waters (NW Atlantic). Fish. Res. 152: $66-73$ http://dx.doi.org/10.1016/j.fishres.2013.09.003

Rodríguez-Domínguez A., Rosas C., Méndez-Loeza I., et al. 2013. Validation of growth increments in stylets, beaks and lenses as ageing tools in Octopus maya. J. Exp. Mar. Biol. Ecol. 449: 194-199. http://dx.doi.org/10.1016/j.jembe.2013.10.001

Sánchez P., Martín P. 1993. Population dynamics of the exploited cephalopod species of the Catalan Sea (NW Mediterranean). Sci. Mar. 57: 153-159.

Semmens J.M., Pecl G.T., Villanueva R., et al. 2004. Understanding octopus growth: patterns, variability and physiology. Mar. Freshwater Res. 55: 367-377. http://dx.doi.org/10.1071/MF03155

Zar J.H. 1984. Biostatistical analysis. Englewood Cliffs, NJ: Prentice-Hall. $718 \mathrm{pp}$ 